\title{
CONTRIBUTION OF THE COOPERATION BETWEEN AGRICULTURE AND TOURISM FOR RURAL DEVELOPMENT
}

Tayfun ÇUKUR, Muğla Sitkı Koçman University, Milas Vocational School, Department of Marketing and Advertising, Milas, Muğla, Turkey, tayfun.cukur@ hotmail.com (corresponding author)

Nuray KIZILASLAN, Tokat Gaziosmanpaşa University, Agricultural Faculty, Department of Agricultural Economics, Tokat, Turkey, nuray.kizilaslan@gop.edu.tr

Figen ÇUKUR, Muğla Sitkı Koçman University, Milas Vocational School, Department of Management and Organization, Milas, Muğla, Turkey, figencukur@hotmail.com

The main goal of rural development is to raise the economic, social and cultural levels of all individuals living in rural areas. Rural development, which is considered to be an important tool in the fight against poverty, increases the quality of life of rural population and improves the work and living conditions of the regions where these people live. With rural development, it is aimed to increase both agricultural and non-agricultural incomes. Undoubtedly, agriculture is the most important source of income for people living in rural areas. However, in recent years, those living in rural areas also generate significant incomes from non-agricultural activities. Rural tourism activities are an important source of income for people living in rural areas. Thanks to rural tourism, entrepreneurs are making investments in rural areas. Thus, income growth is experienced in rural areas and employment is increasing. Rural tourism also makes important contributions to the sustainability of the local culture. On the other hand, rural tourism is an alternative field of activity where farmers can make better use of their free time. Through rural tourism, rural-urban migration can be prevented. This is important for the sustainability of rural areas. The current study primarily discusses the concepts of rural development and rural tourism. The interaction between agriculture and tourism is examined and the benefits of rural tourism are uncovered. The results of the study have shown that rural tourism activities have positive effects on rural development.

Keywords: agriculture, rural development, tourism

\section{INTRODUCTION}

One of the most important goals of rural development is to raise the living standards of rural population. Of course, one way to achieve this is to diversify the rural economy. In this context, rural income can be increased by means of agriculture-related or non-agricultural alternative activities appropriate to local conditions. Rural tourism activities can be considered as a very suitable activity in terms of diversification of rural economy. The basis of these activities is provided by rural areas, agricultural organizations, natural sources, country landscape, agricultural production, rural heritage and farmers. On the other hand, the recent decline in the agricultural population in the world is a major threat to the socio-economic continuity of rural areas. Moreover, the increase in imported products due to the liberalization of international trade is an important economic problem for rural areas. Rural tourism can be used as an important tool for solving these problems (Shin et al., 2017). It is also thought that rural tourism can play a role in preventing migration from rural to urban areas. In recent years, rural tourism has been recognized as a suitable alternative for the promotion of rural development, for the creation of synergy with the traditional agricultural activities of small local business, particularly with agriculture (Badulescu, Badulescu, 2017).

Tourism is an important sector contributing to the development of many rural areas, creating new employment opportunities and increasing the attractiveness of rural areas. With the policies of rural development, tourism activities can be developed in rural areas because rural areas offer opportunities for the growth and development of new sectors (ENRD, 2013).

In most developing countries, non-agricultural activities for rural populations have become an important component of livelihood strategies. When agriculture becomes less profitable and more risky and when population growth and product and market failures occur, non-agricultural activities become an alternative for farmers (Babatunde, Qaim, 2009). Tourism activities have an important place among rural non-agricultural activities. Therefore, achievement of the agriculture-tourism integration is important for rural development.

When the tourism activities in rural areas are examined, two concepts come to the fore: rural tourism and agricultural tourism. Rural tourism is a kind of tourism performed in rural areas (OECD, 1994). According to another definition, rural tourism can be defined as a rural experience that includes many tourist activities in agricultural or nonurban areas (Irshad, 2010). Some of the remarkable characteristics of rural tourism are the following: Rural tourism; 
- is performed in rural areas,

- $\quad$ is small-scale, is performed in open areas and is closely associated with nature, inheritance and traditional applications,

- has a low growth speed,

- adopts a sustainable perspective for the good use of sources,

- $\quad$ has different norms covering the dimensions of environment, history, economy (Fotiadis, 2009).

The scope of rural tourism activities is very wide. Lodging-houses, accommodation, restaurant, breakfast houses and facilities to be established within the scope of farm tourism, sports activities, nature trips, historical excursions, and plateau tourism are just some of the activities carried out within the scope of rural tourism. The economic, social-cultural and ecological benefits of rural tourism are shown in Table 1.

Table 1: Benefits of rural tourism

\begin{tabular}{|c|c|c|}
\hline Economic & Socio-cultural & Ecologic \\
\hline $\begin{array}{l}\text {-Gross national product increase } \\
\text {-Decreasing unemployment } \\
\text {-Job opportunities (accommodation, } \\
\text { food and beverage services, commerce, } \\
\text { entertainment) } \\
\text {-Increase in the local and national } \\
\text { income } \\
\text {-Increasing attention of foreign } \\
\text { investments } \\
\text {-Supporting growth and diversity in } \\
\text { other sectors (local handcrafts, } \\
\text { manufacturing and agriculture) } \\
\text {-Improving infrastructure }\end{array}$ & $\begin{array}{l}\text {-Cultural interaction } \\
\text {-Revival of cultural activities } \\
\text {-Promotion of social integration (closer } \\
\text { contacts between local people and } \\
\text { tourists), social participation } \\
\text {-Protection of cultural heritage, } \\
\text { protection and promotion of local } \\
\text { cultural values, promotion of local } \\
\text { people's initiatives }\end{array}$ & $\begin{array}{l}\text {-Environmental protection (protection } \\
\text { of natural areas) } \\
\text {-Improving infrastructure, protection of } \\
\text { landscapes }\end{array}$ \\
\hline
\end{tabular}

Source: Vadymovich, 2016.

Agricultural enterprises offer food and fiber production as well as other opportunities for society. While some of these opportunities are related to marketable goods, some of them are related to non-marketable goods. Agricultural tourism activities can be seen among marketable opportunities (Carpio et al., 2008). Agricultural tourism is a sub-set of rural tourism. Agricultural tourism is based on the use of agricultural activities for tourism purposes. Agricultural tourism is based on the principle of visiting an active agricultural enterprise for participating in entertainment, education and activities (Gao et al., 2014). Direct participation in agricultural activities (collecting fruit, milking cows), indirect participation in farm activities (shopping at farmers' markets), recreational activities where farm facilities serve only as landscaping (joining a wedding reception in a vineyard), accommodation at the farm (bed and breakfast) and food services are just some of the activities that can be conducted within the scope of agricultural tourism (Barbieri, 2013).

Agricultural tourism can undertake important tasks, especially in local development works of rural marginal areas or in areas where environmental and cultural heritage is highly appreciated by tourists (Mirela, 2016).

In this study, agriculture-tourism interaction in rural areas will be discussed in terms of rural development, and suggestions will be made to make the relationship between agriculture and tourism sectors more effective.

\section{MATERIAL AND METHOD}

The main material of the current study is the data collected from second-hand sources. In this study, published articles and researches related to the subject and reports published by various institutions and organizations have been widely used. In this study, thematic review has been made and the related studies have been examined and some comments have been made about this subject.

\section{AGRICULTURE-TOURISM INTERACTION}

Agriculture and tourism are important sectors of the world economy and are an important source of livelihood providing food and jobs for many people. The tourism sector is a new and rapidly growing industry compared to the agricultural sector. Creating synergy between these two sectors will also contribute to the rapid development of both of them (Vafadari, 2013).

Tourism has the potential to stimulate demand in the agricultural sector, so it is important to improve the relationship between these two sectors. With the development of relations between agriculture and tourism, agricultural income increases, new markets and products are developed and thus sustainable economic growth can be achieved (Anonymous, 2015).

There is a multifaceted, complex and variable relationship between tourism and agriculture in developing countries. While there is a competition between agriculture and tourism in terms of land, water and labor, the tourism sector buys local agricultural products and farmlands are used for agricultural tourism (Rogerson, 2012). Among the 
factors affecting the strength and type of ties between tourism and agriculture are there factors related to demand, supply and marketing (Table 2).

Table 2: Factors affecting the strength and type of ties between tourism and agriculture

\begin{tabular}{|c|c|c|}
\hline Factors related to demand & Factors related to supply & Marketing-related factors \\
\hline $\begin{array}{l}\text {-Type of tourism development, type of } \\
\text { visitor, accommodation in terms of size } \\
\text { and class } \\
\text {-Maturity of tourism industry } \\
\text {-Promotion of local cuisine and } \\
\text { capacity of using locally creative } \\
\text { products }\end{array}$ & $\begin{array}{l}\text {-Existence of natural resources; } \\
\text { physical limitations to } \\
\text { production (products, live } \\
\text { animals and fish) } \\
\text {-Well-established production } \\
\text { models (for example, } \\
\text { agricultural products for export) } \\
\text {-Quantity and quality of local } \\
\text { production } \\
\text {-Price competitive power of } \\
\text { locally produced agricultural } \\
\text { products } \\
\text {-Limitations in technology and } \\
\text { processing } \\
\text {-Health and security standards in } \\
\text { practice }\end{array}$ & $\begin{array}{l}\text {-Political framework } \\
\text {-Marketing and infrastructure restrictions } \\
\text {-Supply determined according to demand } \\
\text {-Spatial and temporal supply models } \\
\text { (including seasonal changes on demand and } \\
\text { supply) }\end{array}$ \\
\hline
\end{tabular}

Source: Rogers, 2012.

The agricultural sector is the market for the tourism sector. The agricultural products produced in the agricultural sector are transferred to the tourism sector; that is, the output of the agricultural sector is an important input for the tourism sector. The most basic relationship between the tourism sector and the agricultural sector occurs in the area of nutrition because the raw materials and inputs of the products that meet the basic eating and drinking needs of domestic and foreign tourists are provided from the agricultural sector. Tourists coming to rural areas through the integration of agriculture and tourism find opportunities to get engaged in activities such as cultivation, harvesting, pruning, milking etc. As it is known, some activities in the agricultural sector have to be done in certain periods. This causes farmers in rural areas to be very busy in certain periods and to be relatively less busy in some other periods. In other words, the labor force of farmers in certain periods may remain idle. Thus, some farmers can work in non-agricultural sectors. This may cause farmers to stay away from agriculture and rural areas. Agricultural tourism activities can be considered as an alternative activity area where the idle labor force of farmers can be utilized. Thanks to agricultural tourism, farmers can obtain the opportunity to earn throughout the 12 months of the year without moving anywhere.

Since the main purpose of agricultural tourism is not the maximization of agricultural production, less chemical input is used. This contributes to protection of environment and nature and prevention of land degradation. It is easy for agricultural tourism farms to adopt organic farming as it is one of the environmental friendly farming techniques because in these enterprises, the use of chemical inputs is relatively less. Farmers on the one hand will increase their business income by making organic farming; on the other hand, agricultural tourism enterprises with organic farming will attract more tourists. Tourists can find fresh, chemical-free healthy agricultural products in these establishments. With rural tourism activities, extra income is created for those living in rural areas on the one hand, and visitors find the opportunity to get to know other cultures on the other.

Rural tourism activities also contribute to the conservation and survival of the cultural heritage of a region. At the same time, rural tourism activities are an alternative to the seasonality problem of agricultural production as farmers can generate income through rural tourism activities. Rural areas are becoming areas where tourism activities can be carried out (plateau tourism, nature photography, canoeing, bird watching, etc.).

\section{DISCUSSION}

Integration of agriculture and tourism in rural areas has economic, ecological and social benefits. Undoubtedly, these benefits form an important infrastructure for rural development. Rural tourism and agricultural tourism activities can be seen as activities that increase employment, income and investments in the countryside, stimulate the rural economy, increase the demand for agricultural products, and support rural entrepreneurship. Therefore, these activities have important contributions to the growth of rural economies and rural development. Agricultural tourism is viewed not only as a means of rural development, but also as a means of reducing poverty in developing countries (Bhatta et al., 2019). When the studies on the subject were examined, it was determined that similar results had been obtained.

In the research conducted by Fischer (2019), it is emphasized that the income of farmers from tourism is important and it is stated that the income obtained from the accommodation of tourists in agricultural enterprises constitutes $10 \%$ of the total agricultural income.

Lupi et al. (2017) emphasize that agricultural tourism activities support rural development by increasing business income and employment and protecting nature.

In the study by Sgroi et al. (2014), it is stated that tourism activities can contribute to the increase in direct sales of traditional products, the economic performance of farms and all rural communities, investments and business opportunities. 
In the study conducted by Choenkwan et al. (2016) in Thailand, it was determined that 1500 people in Phu Ruea district participated in agricultural tourism activities and $90 \%$ of them were farmers or family members of farmers. In the study, it was determined that agricultural tourism activities increased farmer income and quality of life of farmers.

In a study conducted by Bhatta et al. (2019) in Nepal, it was determined that farmers between 21-40 years old, farmers returning from abroad and relatively educated farmers carry out agricultural tourism activities.

In the research carried out by Yang (2012), it was determined that agricultural tourism contributes to the protection of the environment and the appreciation of the rural life as well as creating additional income and new employment areas for the rural society.

In the research conducted by Tew, Barbieri (2012), it was determined that agricultural tourism activities increase the number of customers in enterprises, educate the society about agriculture, increase the quality of life of the farmer family and these activities have both economic and non-economic benefits.

Both farmers and tourists win in agricultural tourism. While farmers benefit by generating additional income, tourists can eat natural foods. On the other hand, since both women and men can work in agricultural tourism activities, gender inequality decreases (Chadda, Bhakare, 2012).

In the research carried out by Schilling et al. (2012), it was determined that farm incomes increased and farm resources were used fully and effectively due to agricultural tourism activities.

In the study conducted by Calado et al. (2011), it was reported that the houses where the families lived were restored with the support of the state because of rural tourism and at the same time extra income was obtained.

In the research conducted by Tanrıvermiş, Şanlı (2007) in the city of Nevşehir, it was found that $73.5 \%$ of the individuals participating in the survey obtained their income from agriculture and $26 \%$ from tourism-related activities.

In the research conducted by Grazulis, Narkuniene (2015), it was determined that $43 \%$ of those who are engaged in rural tourism plan to expand their business.

Ciolac et al. (2013) stated that due to agricultural tourism, agricultural tourism structures have been created to attract tourists all year round, including summer and winter, and complex rural tourism packages including recreation, entertainment, environmental education, cultural traditions and folkloric products are offered to tourists.

Shehrawat et al. (2011) found that $95 \%$ of the farmers surveyed think that agricultural tourism activities increased their income, $87.50 \%$ think that these activities increased the knowledge of the farmers and $90 \%$ think that they were beneficial for the small farmers with low soil fertility.

\section{RESULT AND SUGGESTIONS}

Rural tourism and agricultural tourism activities are an important activity increasing the income of rural population. The gradual decline in the agricultural population in the world further increases the importance of rural tourism activities. These activities can be considered as a means to prevent migration from rural to urban areas and can be considered as an important policy tool in ensuring the socio-economic continuity of rural areas. Rural tourism activities play a significant role in ensuring sustainable rural development. Because rural tourism activities use local resources and local stakeholders, it promotes local development and rural development. Rural tourism activities contribute to rural development by protecting and transferring natural, cultural and rural heritage in rural areas to future generations.

In recent years, entrepreneurship has become a very important concept. Rural tourism activities can be considered as an important factor in the development of entrepreneurial spirit in rural areas. On the other hand, these activities are very important in terms of the development of women's entrepreneurship in rural areas.

Tourists coming to rural areas as a result of the integration of agricultural and tourism activities have the opportunity to see and participate in agricultural activities and other activities (handicrafts, etc.). On the other hand, these activities are seen as a means of escaping from the crowd and noise of the city. Measures to be taken in terms of strengthening and developing the relationship between agricultural and tourism activities in rural areas may be:

- Investments in rural tourism should be supported by the Agriculture and Rural Development Support Agency (IPARD). Increasing the number of provinces to be supported and the amount of support budgets will undoubtedly contribute to the development of rural tourism.

- Natural resources and ecosystems are on the centre of rural tourism activities. For this reason, measures should be taken to increase awareness of environmental protection in agricultural and tourism activities.

- Rural tourism activities are an important activity increasing the quality of life of rural people. In this respect, studies should be conducted to determine the rural people's viewpoints on rural tourism activities.

- Incentives and subsides given to rural tourism activities having greater environmental awareness than mass tourism should be increased.

\section{REFERENCES}

1. Anonymous. 2015. Linking Agriculture and Tourism through Policy Setting Organised by IICA, the Government of Vanuatu and CTA, IICA Office, Baobab Tower, St. Michael, Barbados.

2. Babatunde, R.O., Qaim, M. 2009. The role of off-farm income diversification in rural Nigeria: Driving forces and household access, p.1-26. Available at https://www.researchgate.net (accessed on 10/12/2019)

3. Badulescu D., Badulescu A. 2017. Rural tourism development through cross-border cooperation. the case of Romanian-Hungarian cross-border area. Eastern European Countryside, Vol. 23, Iss.1, pp. 191-205. https://doi.org/10.1515/eec-2017-0009 
4. Barbieri C. 2013. Assessing the sustainability of agritourism in the US: a comparison between agritourism and other farm entrepreneurial ventures. Journal of Sustainable Tourism, Vol. 21, Iss.2, pp. $252-270$. https://doi.org/10.1080/09669582.2012.685174

5. Bhatta K., Itagaki K., Ohe Y. 2019. Determinant factors of farmers' willingness to start agritourism in rural Nepal. Open Agriculture, Vol. 4, Iss.1, pp. 431-545. https://doi.org/10.1515/opag-2019-0043

6. Calado L., Rodrigues A., Silveira P. Dentinho,T. 2011. Rural tourism associated with agriculture as an economic alternative for the farmers. European Journal of Tourism, Hospitality and Recreation, Vol. 2, Iss.1, pp. 155-174.

7. Carpio C.E., Wohlgenant M.K., Boonsaeng T. 2008. The demand for agritourism in the United States. Journal of Agricultural and Resource Economics Association, Vol. 33, Iss.2, pp. 254-269.

8. Chadda D., Bhakare S. 2012. Socio-economic implications of agri tourism in India. International Proceedings of Economics Development and Research, Vol.39, pp.151-155.

9. Ciolac R., Petroman C., Petroman I., Rujescu C., Stanciu S., Martin S., Tucudean A. R. 2013. Research of agro tourism stage and traditional products through activity in the Alps mountain Trento province. Proceedings of the International Scientific Conference "Rural Development 2013" Vol. 6, Book 1, 74-79, Aleksandras Stulginskis University.

10. Choenkwan S., Promkhambut A., Hayao F., Rambo A.T. 2016. Does agrotourism benefit mountain farmers? a case study in Phu Ruea District, Northeast Thailand. Mountain Research and Development, Vol. 36, Iss.2, pp. $162-172$. https://doi.org/10.1659/MRD-JOURNAL-D-15-00111.1

11. European Network for Rural Development (ENRD). 2013. Encouraging diversification of the rural economy, Thematic Information Sheets 2007-2012, Rural Development Programmes 2007-2013.

12. Fischer, C. 2019. Agriculture and tourism sector linkages: Global relevance and local evidence for the case of South Tyrol, Open Agriculture, Vol. 4, Iss.1, pp. 544-553. https://doi.org/10.1515/opag-2019-0053

13. Fotiadis A. 2009. The role of tourism in rural development through a comparative analysis of a Greek and a Hungarian rural tourism area, Phd thesis, University of Pecs Faculty of Business and Economics, Hungary.

14. Gao J., Barbieri C., Valdivia C. 2014. Agricultural landscape preferences: implications for agritourism development, Journal of Travel Research, Vol. 53, Iss.3, pp. 366-379. https://doi.org/10.1177/0047287513496471

15. Grazulis, V., Narkuniene, R. 2015. The assumptions of successful development of rural tourism in Lithuania (case study of Eastern Aukstaitija region), Proceedings of the 7th International Scientific Conference Rural Development 2015, pp. 1-6. https://doi.org/10.15544/RD.2015.124

16. Irshad H. 2010. Rural Tourism- An Overview. Government of Alberta Agriculture and Rural Development, 29p.

17. Lupi C., Giaccio V., Mastronardi L., Giannelli A., Scardera A. 2017. Exploring the features of agritourism and its contribution to rural development in Italy. Land Use Policy, Vol. 64, pp. 383-390. https://doi.org/10.1016/j.landusepol.2017.03.002

18. OECD, 1994. Tourism Strategies and Rural Development, 94p. Paris.

19. Mirela C.S. 2016. Agrotourism and gastronomic tourism, parts of sustainable tourism. Journal of Horticulture, Forestry and Biotechnology, Vol. 20, Iss.3, pp. 106-109.

20. Rogers T.S. 2012. Study to Assess Constraints, Potentials Increase the Understanding of Policy and Institutional Arrangements Needed to Enchance Synergies, FAO Sub-Regional Office for The Pacific Islands Report on a Scoping Mission in Samoa and Tonga Agriculture and Tourism Linkages in Pacific Island Countries.

21. Rogerson C. M. 2012. Tourism-agriculture linkages in rural South Africa: evidence from the accommodation sector. Journal of Sustainable Tourism, Vol. 20, Iss.3, pp. 477-495. https://doi.org/10.1080/09669582.2011.617825

22. Sgroi F., Di Trapani A.M., Testa R., Tudisca,S. 2014. The rural tourism as development opportunity or farms. The case of direct sales in Sicily. American Journal of Agricultural and Biological Sciences, Vol. 9, Iss.3, pp. $407-419$. https://doi.org/10.3844/ajabssp.2014.407.419

23. Schilling B. J., Sullivan K. P., Komar S. J. 2012. Examining the economic benefits of agritourism: The case of New Jersey. Journal of Agriculture, Food Systems, and Community Development, Vol. 3, Iss.1, pp. $199-214$. https://doi.org/10.5304/jafscd.2012.031.011

24. Shehrawat P.S., Mehta S. K., Huda R. S. 2011. Agricultural Tourism for Sustainable Rural Development. Proceedings of the International Scientific Conference Rural Development, Vol. 5, Book 1, 243-248, Aleksandras Stulginskis University.

25. Shin H.J., Kim H.N., Son J.Y. 2017. Measuring the economic impact of rural tourism membership on local economy: A Korean case study. Sustainability, Vol. 9, pp. 639. https://doi.org/10.3390/su9040639

26. Tanrıvermiş H., Şanl H. 2007. A research on the impacts of tourism on rural household income and farm enterprises: the case of the Nevşehir Province of Turkey. Journal of Agriculture and Rural Development in the Tropics and Subtropics, Vol.108, Iss.2, pp.169-189.

27. Tew C., Barbieri C. 2012. The perceived benefits of agritourism: The provider's perspective. Tourism Management, Vol. 33, pp. 215-224. https://doi.org/10.1016/j.tourman.2011.02.005

28. Vadymovich B.A. 2016. Innovative Approaches of Regional Policy of Rural Tourism Development, Associaçao de Politecnicos Do Norte (Apnor) Instituto Politecnico De Bragança.

29. Vafadari K. 2013. Planning sustainable tourism for agricultural heritage landscapes. Ritsumeikan Journal of Asia Pacific Studies, Vol. 32, pp. 75-89.

30. Yang L. 2012. Impacts and challenges in agritourism development in Yunnan, China. Tourism Planning \& Development, Vol. 9 , Iss.4, pp. 369-381. https://doi.org/10.1080/21568316.2012.726257 